\title{
The Impact of HR Policies over the Financial Soundness of Commercial Banks: A Study on Dhaka Bank Limited
}

ISSN: 2311-8636 (Print) ISSN: 2312-2021 (Online)

DOI prefix: 10.18034/ajhal

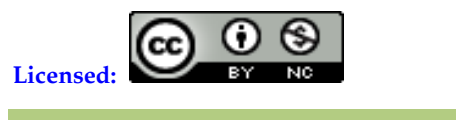

Source of Support: Nil

No Conflict of Interest: Declared

*Email for correspondence: safa.bnkng.du@gmail.com

an exception. Banking is one of the most significant sectors of the world economy and especially in a developing country like Bangladesh. Bank employees are the representative of the bank as it is a service-oriented organization, and they are providing banking services to the clients. The more customers' retention will lead to more revenue as well as financial profit. The banks are now more concern about their employee's development to make sure the highest productivity of their employees. The paper shows the importance of efficiency and effectiveness of HR policies to upward financial profit and sustainable growth of the bank. Dhaka Bank Limited (DBL) has taken as a sample bank among all the private commercial banks in Bangladesh to conduct the study. The study includes both descriptive as well as quantitative analysis like showing performance by using financial ratios and the impact of HR costs over the profitability. Sample survey has done among the DBL employees to collect data for the study. The study discloses that the banks are investing the huge amount of fund to develop HR strategies and to motivate employees so that the employee turnover will reduce and productivity will increase which leads to better performance to make sure financial profitability and growth. Usually to maintain all rules and regulation of $\mathrm{HR}$, the banks have to expense more but its conveying long-term productive effect on business growth. It also creates a competitive advantage of the bank to compete with others bank. This study may be helpful for banks regarding dealing with profitability and HR strategies.

Key Words: Financial Profitability, Human Resources Policies, Employee's Productivity, Employee Retention, Financial Stability, Sustainable Growth 


\section{INTRODUCTION}

Banking is a very fundamental part of an economy and plays very considerable contribution towards the socio-economic progress of a country. The Banking sector is considered to be like the life blood the economy as well as one of the most important components of the financial system it forms the core of the money market and plays a very pivotal role in mobilizing resources for productive investments in a country which in turn contributes to economic development. Among the factors creating the effect on financial profitability of banks, Human Resource Management (HRM) Policy is one of the most important factors. It contains recruitment and selection, compensation, orientation, performance appraisal, rewards and many more accomplishments linked to human resources. For an organization human resource is always considers as important as financial resources and for banks it's inevitable. Bankers or bank employees are the key points for the overall growth of the banks. A banker is the representative of a bank. So to maintain these human resources the banks needs to follow all the rules and regulation of the human resources policy and also make sure the effective use of such guidelines in regular human resource related activities. The problem statement of the paper is that whether HR policies and management create significant impact on the profit growth and financial performance of the commercial banks or not. The overall goal of the study is to explore every potential human resource policy that is very effective for the financial soundness of a government bank and a private bank. The second section focuses on the research questions. The third session focuses on reviewing literature. The next session focuses on the objectives. The fifth section shows the HR practices done by the selected bank along with bank profile. The following section highlights in the descriptive analysis. The seventh segment focuses on findings and last section emphases on the conclusion.

\section{RESEARCH QUESTIONS}

Specifically, this paper has undertaken to explore the answer to the subsequent research questions (RQ):

$\mathrm{RQ}_{1}$ : Is there any connection between HR Practices and Financial Performance of commercial banks?

$\mathrm{RQ}_{2}$ : Do HR practices have any significant impact on Profitability of commercial banks?

\section{LITERATURE REVIEW}

\section{Theoretical Background}

HRM is composed of the policies, practices, and systems that influence employees' behavior, attitude, and performance (Noe, Hollenbeck, Gerhart, \& Wright, 2007, p. 5) Human resource management (HRM) practices is regard as one of the major contributory factors in the financial performance of organizations. This research study effectively highlights the importance of HRM practices with impact on financial performance of commercial banks by focusing on sample bank Dhaka bank Ltd.

Banks use the following model of Gary Dessler (2005,p-152 ) as Recruitment \& Selection Process. Dhaka Bank also uses it for the same purpose. 


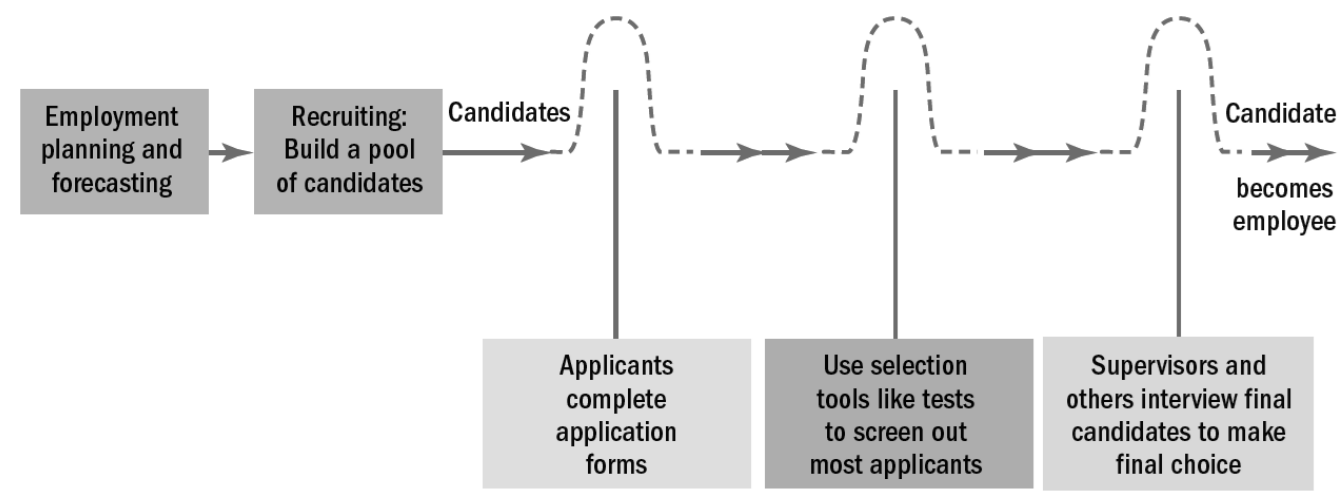

In this model he describe about the recruitment and selection process steps.

Dhaka Bank Limited uses following model of Gary Dessler (2005, p- 270) for Training Process which shows as follows;

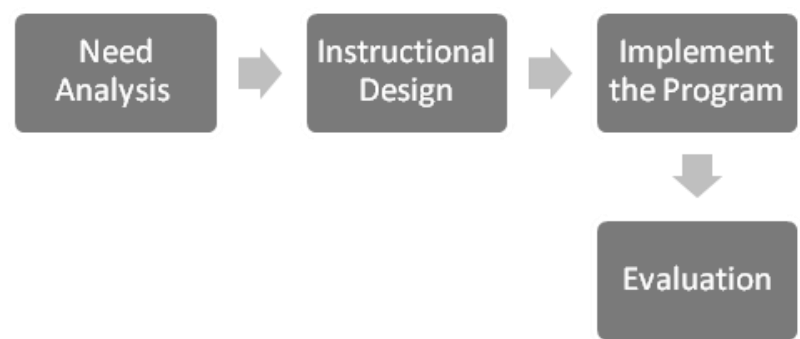

In this model, he describes the steps of training process which includes -Training needs analysis, Instructional Design, Implement the Program, and Training evaluation. He also describes the Training and development delivery process which are on the job training and off the job training.

The bank also uses following Gary Dessler model (2005, p-398) for Establishing Pay Rates.

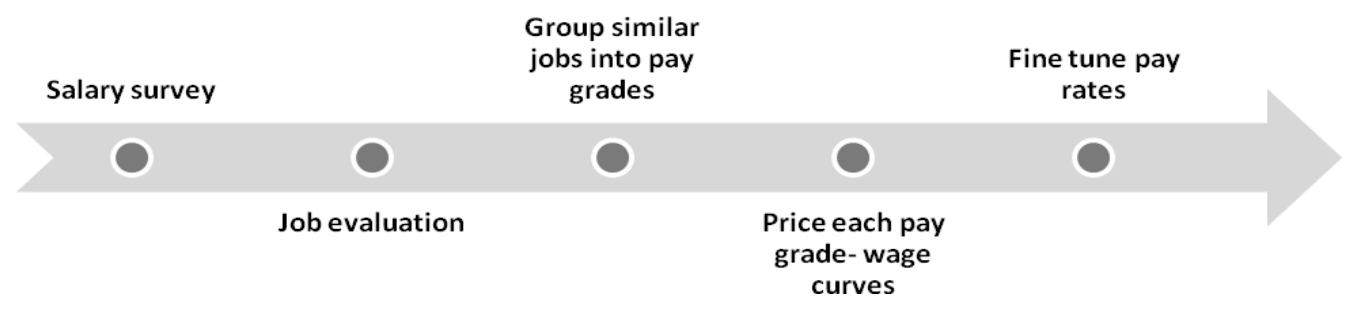

By this model he describes about the Establishing Pay Rates steps which includes- the salary survey, job evaluation, group similar jobs into pay grades, price each pay gradewage curves and fine tune pay rates.

\section{HR practices and financial profitability}

The ultimate goal of a business organization is higher financial performance or maximization of wealth for stock holders (Becker \& Huselid, 1998; Horngren, Foster, \& Datar, 2000). Nonetheless, attaining the organization's goals depends upon the extent to which its organizational performance is reached (Katou \& Budhwar, 2007). 
Absar, Nimalathasan, and Jilani (2010) studied over 85 manufacturing companies listed in Chittagong Stock Exchange (CSE) was prepared (Chittagong Stock Exchange, 2010) by providing the structured questionnaire to the HR managers of the all 85 manufacturing companies to demonstrate the effect of HR policies over the organization performance. In Accordance to Fomburn, Tichy, and Devanna, (1984) they selected Recruitment and Selection (RS), Training and Development (TD), Performance Appraisal (PA) and Compensation (COM) as independent variables and organizational performance (OP) as a dependent variable. They concluded that the highest positive value of correlation between PA and OP clarifies that the authorities of selected manufacturing firms are required to give focus on PA for getting fabulous organizational performance.

Arguments made in related research are that a firm's current and potential human resources have considerations in the productivity and efficiency of a firm. This literature, although mostly theoretical, concludes that human resource management policies can help to build a source of sustained competitive advantage, especially when they are associated with a firm's competitive strategy (Begin, 1991; Butler, Ferris, \& Napier, 1991; Cappelli \& Singh, 1992; Jackson \& Schuler, 1995; Porter, 1985; Schuler, 1992; Wright \& McMahan, 1992).

Moyeen and Huq (2001) studied HRM practices of 92 medium and large business enterprises (public and private sector) located in Dhaka, Bangladesh. They found that only $62 \%$ of surveyed organizations had an HR/Industrial Relations (IR) department.

There is a growing consensus that organizational human resource policies can grant a direct and economically important contribution to firm performance. The assumption is that more effective systems of HRM practices, which simultaneously exploit the potential for complementarities or synergies among such practices and help to implement a firm's competitive strategy, are sources of sustained competitive advantage.

Research on the impact of HRM practices on organizational productivity is extensive. Cutcher-Gershenfeld (1991) found that firms adopting "transformational" labor relationsthose emphasizing cooperation and dispute among lower costs, less scrap, higher productivity, and a greater return to direct labor hours than did firms using "traditional" adversarial labor relations practices. Katz, Kochan, and Weber (1985) revealed that effective industrial relations systems, defined as those with fewer grievances and disciplinary actions and lower absenteeism, increased product quality and direct labor efficiency, and Katz, Kochan, and Keefe (1987) showed that some innovative work practices improved productivity. Katz, Kochan, and Gobeille (1983) and Schuster (1983) found that quality of work life (QWL), quality circles, and labor-management teams increased productivity. Bartel (1994) established a link between the adoption of training programs and productivity growth, and Holzer (1987) showed that extensive recruiting efforts increased productivity. Guzzo, Jette, and Katzell's (1985) meta-analysis demonstrated that training, goal setting and socio-technical systems design had significant and positive effects on productivity. Links between incentive compensation systems and productivity have consistently been found as well (Gerhart \&Milkovich, 1992; Weitzman \& Kruse, 1990). Finally, employee turnover also has an influence on organizational productivity (Brown \& Medoff, 1978).

Prior empirical work has consistently found that use of effective human resource management practices enhances firm performance. Specifically, extensive recruitment, selection, and training procedures; formal information sharing, attitude assessment, job design, grievance procedures, and labor-management participation programs; and 
performance appraisal, promotion, and incentive compensation systems that recognize and reward employee merit have all been widely linked with valued firm-level outcomes.

Ichniowski, Shaw, and Prennushi (1993) using longitudinal data from 30 steel plants, found the impact of "cooperative and innovative" HRM practices to have a positive and significant effect on organizational productivity. Similarly, Arthur (1994) found in 30 steel "mini-mills" that those with "commitment" human resource systems, emphasizing the development of employee commitment, had lower turnover and scrap rates and higher productivity than firms with "control" systems, emphasizing efficiency and the reduction of labor costs. Finally, MacDuffie (1995) found that "bundles" of internally consistent HRM practices were associated with higher productivity and quality in 62 automotive assembly plants. Each of these studies has focused on the impact of systems of High-Performance Work Practices on employee turnover or productivity.

Few studies, however, did not find clear effects of HRM practices on productivity (Delaney et al., 1989).Batt (2004) found that HRM practices do not pay off in small organizations that operate in local markets. Cappelli and Newmark (2001) identified that human resource management practices may raise productivity slightly, but they also raise labor costs. Huselid (1995) evaluated that HRM practices are statistically significant and having a positive effect on the corporate financial performance of the organization.

According to Nicholas Bloom \& John Van Reenen (2010), variations in HRM practices play a role in driving differences in and productivity in organizations. Ram Phool Sharma and Seema Mehlawat (2011) those banks which have promoted the Human Resource Management Strategies and Business Strategies in the field of Promotion, Training, Reward System, Productivity, Job Security and Placement are performing better in the present time.

According to Gayatri Panda and Sisira Kanti Mishra (2013) providing every opportunity for assuming greater responsibility, promotion, value-added job, meaningful and worthwhile job, and learning culture certainly enable employees to grow and develop to a larger extent. Therefore, committed employees are expected to understand, share and support the company's vision and goals and consistently try towards achieving them.

The basic literature gap between our study and others is that previous authors mainly showed the connection of HR practices with the overall performance of the firm. Some of them drawn a conclusion about the connectivity of HR policies and manufacturing firm's performances. Some authors only show that the impact of HR practices in service sector like as commercial banks (Talukder, Hossain \& Hossain, 2014). Our study mainly focuses on the impact of HR policies over the commercial bank's profit growth.

\section{OBJECTIVES OF THE STUDY}

Specific Objectives of the study is as follows;

- To examine the nature of human resource policies practiced in Commercial banks of Bangladesh in the light of Dhaka Bank limited.

- To scrutinize the employees' view regarding different levels of their job satisfaction by some pre-selected determinants.

- To explore the approximate size of the budget provided to operate the present human resource policy.

- To identify whether there is a positive and significant statistical relationship between human resource policies and financial soundness of a bank. 


\section{Methodology}

In this paper, we have used quantitative techniques to analyze the significance of the study. It is an empirical type of research which may use for further research works. Following research methodologies is following for the present study;

\section{Data sources:}

We have collected information from both sources primary as well as secondary.

For the study, a questionnaire has constructed and given to the employees of the selected bank to measure the impact of HR development over the financial growth and profitability of a country which is the one of the primary sources of the paper. Secondary data has also used such as ratios, financial figures and so on.

\section{Sample:}

We have collected information via using questionnaire among the employees from different branches of Dhaka of this selected bank. For the paper, 50 questionnaires are given to the employees of Dhaka Bank Ltd. as a sample of our research. The main focus of the survey is the finance department and HR department. However, only 30 copies of the questionnaire were usable for analysis. So the response rate is $60 \%$.

\section{Instrumentation:}

The questionnaire used in this study established by using 5- point Likert scale with: $5=$ strongly agree, $4=$ agree, $3=$ neutral, 2 = disagree, and $1=$ strongly disagree.

A set of questions have used to justify each variable are as follows;

- Recruitment and selection

- Manipulation

- Attitudes and behavior

- Testing

- Training and Development

- Compensation

- Performance appraisal

- Rewards

- Financial Profitability

Another primary source of data is face-to-face interview which has been done by the high officials of the bank to reveal the present scenario of the bank and its future strategy to gear up profitability.

The study comprises secondary data such as Annual Reports on the selected bank, the related website, articles and so on.

To analyze the research question different types of tools are used like, graphical presentation has done to show the perception of the employees regarding the issue;

Statistical analysis of secondary data has done as well.

For the regression and another statistical analysis Return on Equity (ROE) is selected as a dependent variable and Operating Income per employee and operating profit per branch as independent variables. ROE is the most useful ratio among the profitability ratios of institutions which reflect the overall financial health of an institutions and a bank is not exceptional. So it has taken as a dependent variable for the study. 
Dupont technique (Donaldson Brown, 1912) has used to justify financial indicators in which Return on Equity (ROE) has considered as a strong indicator to justify financial health of a commercial bank.

$R O E=\frac{\text { Net Income }}{\text { Total sales }} \times \frac{\text { Total Sales }}{\text { Total Assets }} \times \frac{\text { Total Assets }}{\text { Total equity }}$

ROE $=$ Profit Margin $\times$ Total Asset Turnover $($ TATO $) \times$ Equity Multiplier

Operating income per employee has taken as independent variable as it shows their efficiency and ability towards the profitability. The higher the operating income per employee, the higher the efficiency of human resources of a bank. Another independent variable, operating income per branch has taken to show that it drives the profitability of the bank but it depends on the efficiency of the particular branch human resource along with its branch location and interior.

We have established the hypothesis as follows:

$H_{0}$ : There is no significant relationship between dependent and independent variables.

$\mathrm{H}_{1}$ : There is a significant relationship between dependent and independent variables.

\section{BANK PROFILE}

\section{Background of the Bank}

The selected bank for the paper is Dhaka Bank Limited (DBL). The Bank has stood out for its financial strength and operational craftsmanship marking its position as the potential market player in all core areas of banking in the country. It got listed on DSE and CSE in 2000. Alongside a lasting bond with the corporate world, DBL has got nationwide grip through a larger network of Branches, ATMs, SME channels, agricultural outreach, and mobile banking. DBL has made its vibrant presence at 77 locations including 2 Islamic Banking Branches, 1 Offshore Banking Unit, 3 SME Service Centers, 1 Business Kiosk and 53 ATMs across the country. Providing to the needs of Capital Markets, the Bank has established a subsidiary company named 'DBL Securities Ltd.' having 6 domestic Branches.

\begin{tabular}{|l|l|}
\hline Establishment & 1995 \\
\hline Authorized Capital & Tk. 10,000 Million \\
\hline Paid-up Capital & Tk. 546.52 Corer \\
\hline Number of branches & 74 \\
\hline Number of Employees & 1,400 \\
\hline
\end{tabular}

Source: Annual Report, 2013(DBL)

\section{HR policy of the Bank}

Human resources are considered the most important assets of an organization, but very few organizations can harness fully to its potential (Ahmed 2002).Almost all the bank in our country uses the similar Human Resource activities and for that reason, we select Dhaka Bank Ltd as a sample to study on it and describe their recent human resources policy. Dhaka Bank Ltd's (DBL) Human Resource Department vision is to create best managed, most productive and efficient workforce and to be one of the best employer's choice among the local banks in Bangladesh. Their HR purpose is to improve productivity or performance of the employee, creating vibrant work culture and accurate compliance for the employee. They select their employee through short listing; competitive examination and personal interview and their HRD are responsible for holding it and relative system confidentially and without any bias. For resource planning, the department always reviews the factors in forecasting 
personnel requirement which include projected employee turnover considering separation of the employee, quality of the existing employee about the future development of the organization and considering the business plans and strategies resourcing the competency based employees. Regarding recruitment sources they use public media such as an advertisement in the newspaper, website or they contract with recruitment agent to select headhunter. DBL HRD always prepares and evaluates their training process to train and improve the skills of the employee and also change it to deal with new opportunities and threats. They analyze their training need by organization, job, and individual. Then they prepare training objectives whether it performance or behavioral. They selected the delivery method such as on-the-job or off-the-job and the evaluation tactics. For training delivery, onthe job includes job rotation and employee development, and off-the-job includes local, inhouse and overseas training. But for a managerial level employee they deliver different development program for on-the-job they select coaching, job rotation and planned work assignment and for off-the-job they select lecture/ seminar, simulation exercise, behavior modeling, and competency based training. In the case of compensation they divided it into three parts respectively, first one salary structure which encompasses- basic salary, housing allowances, living, medical, car/ conveyance second part is annual increment and the third part is a bonus which includes- festival and performance bonus. They also give different kinds of leave to the employees which comprise earned leave (max 30days), casual leave (max10days), sick leave (max 15 days), maternity leave (max 180 days), quarantine leave (max 14 days), pilgrimage leave ( $\max 15$ days subject to 5 years active service). There also some leave without pay, they are- extraordinary leave (max 180 days) and study leave (subject to 3 years continuous active service). Maintaining anticipated performance of every employee DBL also follow a Performance Management Cycle which is showing below:

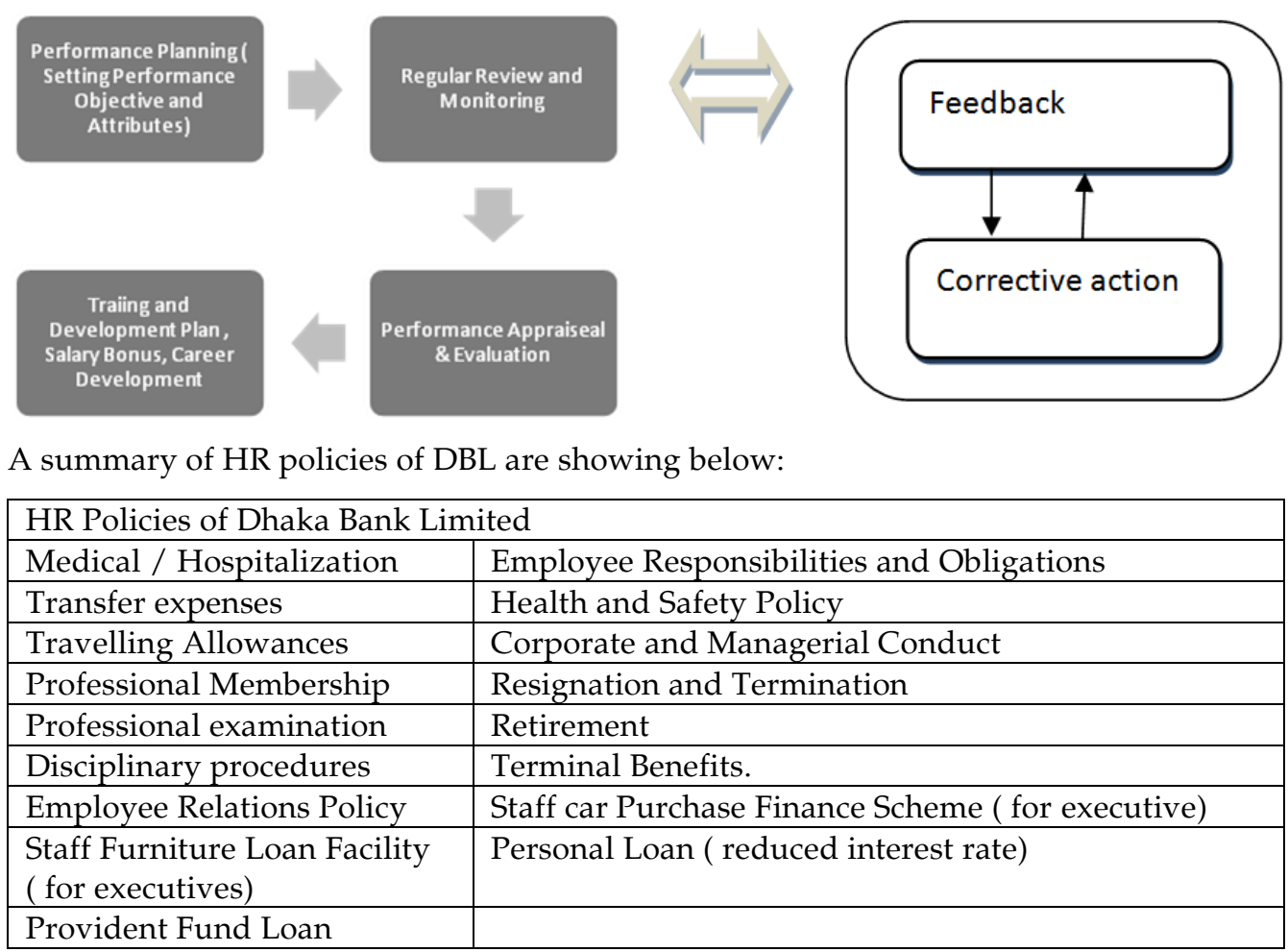


Next three years HR plan of DBL:

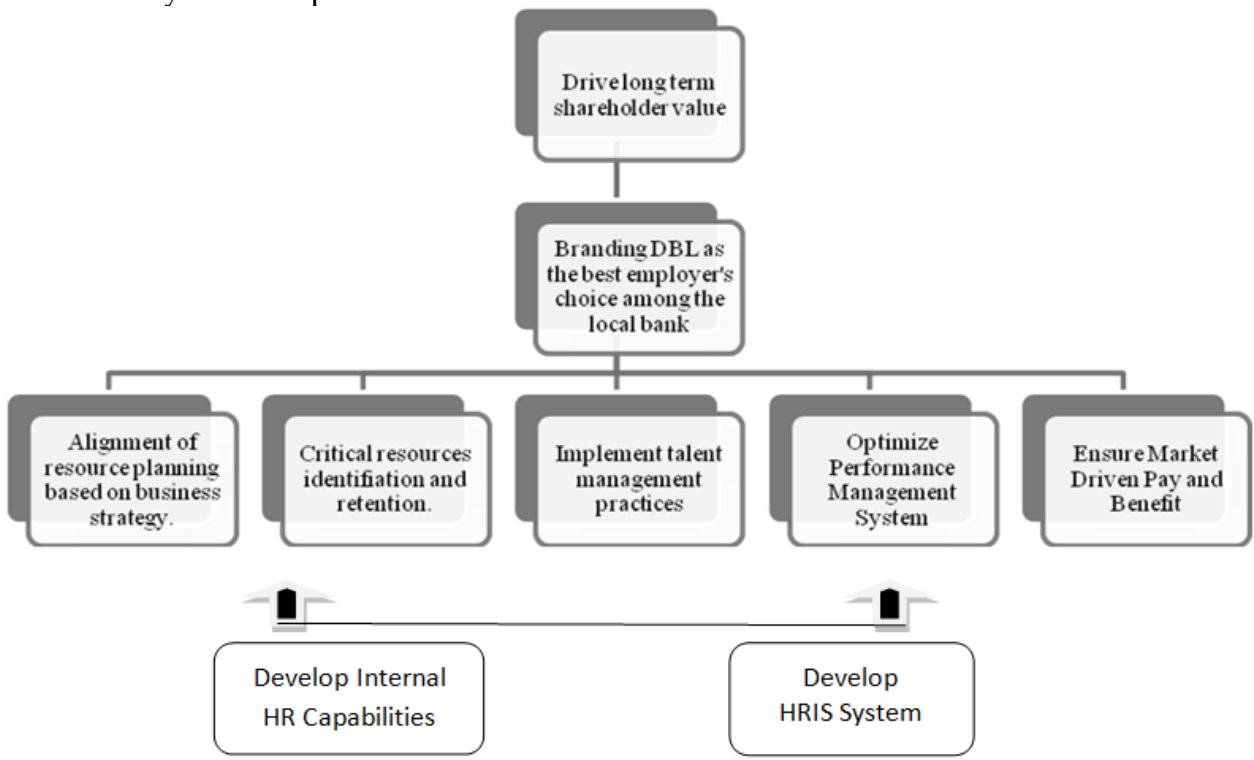

SWOT Analysis:

\begin{tabular}{|c|c|c|}
\hline \multirow{2}{*}{$\begin{array}{l}\text { Internal } \\
\text { Environment }\end{array}$} & Strengths & Weaknesses \\
\hline & $\begin{array}{l}\text { - Centralized HR process. } \\
\text { - Recruitment process and } \\
\text { resource planning. } \\
\text { - Effective performance appraisal. } \\
\text { - Competency based training program. }\end{array}$ & $\begin{array}{l}\text { - Insufficient HR information. } \\
\text { - Imbalance on job recruitment and skill } \\
\text { set matching. } \\
\text { - The expectation for higher } \\
\text { compensation. }\end{array}$ \\
\hline \multirow{2}{*}{$\begin{array}{l}\text { External } \\
\text { Environment }\end{array}$} & Opportunities & Threats \\
\hline & $\begin{array}{l}\text { - Modern HR tools and } \\
\text { technique. }\end{array}$ & $\begin{array}{l}\text { - Higher competition. } \\
\text { - High turnover rate. } \\
\text { - Attracting talent from the market } \\
\text { - HR information. } \\
\text { - Job Requirement and skill set matching. } \\
\text { - Employee's compensation. }\end{array}$ \\
\hline
\end{tabular}

Source: HR Department, Dhaka Bank Limited(2014)

\subsection{Financial status of the bank}

The following table will show the current financial status of the bank.

\begin{tabular}{|l|l|l|l|l|l|}
\hline & 2009 & 2010 & 2011 & 2012 & 2013 \\
\hline Loans & 52,910 & 63,591 & 75,983 & 90,140 & 99,596 \\
\hline Deposits & 60,918 & 70,420 & 85,277 & 107,427 & 115,981 \\
\hline Hr costs & 722 & 967 & 1,049 & 1,184 & 1,483 \\
\hline Number of employees & 924 & 1,109 & 1,207 & 1,412 & 1,400 \\
\hline Number of branches & 50 & 56 & 61 & 71 & 74 \\
\hline Total operating costs & 1,275 & 1,715 & 1,945 & 2,119 & 2,717 \\
\hline Total operating income & 4,086 & 5,555 & 6,228 & 5,343 & 6,410 \\
\hline Total assets & 78,000 & 90,000 & 105,000 & 133,000 & 144,000 \\
\hline NPAT & 959 & 1,679 & 2,165 & 701 & 1,927 \\
\hline
\end{tabular}


Some important financial indicators or ratios are as follows;

\begin{tabular}{|l|l|l|l|l|l|}
\hline & 2009 & 2010 & 2011 & 2012 & 2013 \\
\hline ROE & 19.32 & 25.52 & 23.49 & 7.24 & 16.21 \\
\hline Loan-to-Deposit ratio & 86.85 & 90.30 & 89.10 & 83.91 & 84.22 \\
\hline NIM & 4.56 & 5.24 & 4.10 & 4.10 & 4.32 \\
\hline CAR & 11.31 & 10.09 & 10.70 & 10.74 & 12.18 \\
\hline EPS(Taka) & 36.07 & 4.68 & 4.64 & 1.30 & 3.56 \\
\hline P/E Ratio(times) & 10.72 & 12.09 & 9.70 & 16.50 & 5.28 \\
\hline HR costs-to-Total costs & $57 \%$ & $56 \%$ & $54 \%$ & $56 \%$ & $55 \%$ \\
\hline NPL-to-Total Loans and Advances & 5.57 & 4.57 & 3.45 & 6.28 & 4.15 \\
\hline
\end{tabular}

Financial information per employee and branch has shown as follows;

\begin{tabular}{|l|l|l|l|l|l|}
\hline & & & & & \\
\hline Income Per Employee & 4.42 & 9.46 & 11.16 & 3.68 & 4.42 \\
\hline Expenses Per Employee & 1.38 & 6.00 & 7.68 & 1.46 & 1.87 \\
\hline Operating Profit Per Employee & 3.04 & 3.46 & 3.48 & 2.22 & 2.56 \\
\hline Operating profit Per Branch & 56.21 & 68.60 & 70.84 & 45.40 & 49.91 \\
\hline
\end{tabular}

\section{ANALYSIS}

\section{Descriptive analysis}

\begin{tabular}{|c|c|c|c|c|c|c|c|c|c|c|}
\hline \multirow[t]{2}{*}{ Particulars } & \multicolumn{2}{|c|}{\begin{tabular}{|c|}
1 \\
Strongly \\
Disagree
\end{tabular}} & \multicolumn{2}{|c|}{$\begin{array}{c}2 \\
\text { Disagree }\end{array}$} & \multicolumn{2}{|c|}{$\begin{array}{c}3 \\
\text { Neutral }\end{array}$} & \multicolumn{2}{|c|}{$\begin{array}{c}4 \\
\text { Agree }\end{array}$} & \multicolumn{2}{|c|}{$\begin{array}{c}5 \\
\text { Strongly } \\
\text { Agree }\end{array}$} \\
\hline & & $\%$ & & $\%$ & & $\%$ & & $\%$ & & $\%$ \\
\hline $\begin{array}{l}\text { 1. A huge pool of candidate is expected no } \\
\text { matter how much the cost is. }\end{array}$ & 5 & 16.67 & 7 & 23.33 & 0 & 0 & 12 & 40 & 0 & 20 \\
\hline $\begin{array}{l}\text { 2. Cost - effectiveness is considered seriously } \\
\text { before initiating any training program. }\end{array}$ & 0 & 0 & 5 & 16.67 & 9 & 30 & 9 & 30 & 7 & 23.33 \\
\hline $\begin{array}{l}\text { 3. Modern technology has widened new } \\
\text { training program for employees which incur } \\
\text { a massive cost. }\end{array}$ & 1 & 3.3 & 6 & 20 & 4 & 13.33 & 15 & 50 & 4 & 13.33 \\
\hline $\begin{array}{l}\text { 4. The cost of T\&D will not hamper the profit } \\
\text { growth if it is use in an effective manner. }\end{array}$ & 0 & 0 & 2 & 0.67 & 6 & 20 & 8 & 26.67 & 14 & 46.67 \\
\hline $\begin{array}{l}\text { 5. Competitive pay and benefits packages are } \\
\text { provided to attract and retain skilled employees. }\end{array}$ & 3 & 10 & 10 & 33.33 & 4 & 13.33 & 10 & 33.33 & 3 & 10 \\
\hline $\begin{array}{l}\text { 6. Profit sharing using as a reward mechanism } \\
\text { for skilled person costs more than increase } \\
\text { profit. }\end{array}$ & 4 & 13.33 & 9 & 30 & 11 & 36,67 & 5 & 16.67 & 1 & 3.33 \\
\hline $\begin{array}{l}\text { 7. Financial soundness of a company depends } \\
\text { on its strong HR policy }\end{array}$ & 0 & 0 & 2 & 6.67 & 5 & 16.67 & 17 & 56.67 & 6 & 20 \\
\hline $\begin{array}{l}\text { 8. Costing for HR development (Recruitment } \\
\text { cost, Training and Development cost, } \\
\text { compensation cost) and maintain HR } \\
\text { practices hamper profitability more than } \\
\text { help it to increase. }\end{array}$ & 13 & 43.33 & 13 & 43.33 & 1 & 3.3 & 3 & 10 & 0 & 0 \\
\hline $\begin{array}{l}\text { 9. Strong motivation will push up the } \\
\text { employees to work in a better proportion } \\
\text { which will help to increase profit }\end{array}$ & 1 & 3.3 & 0 & 0 & 1 & 3.3 & 9 & 30 & 19 & 63.33 \\
\hline $\begin{array}{l}\text { 10. An Organization requires qualified and } \\
\text { efficient employees for sales growth and profit }\end{array}$ & 0 & 0 & 1 & 3.3 & 1 & 3.3 & 620 & & 22 & 73.35 \\
\hline
\end{tabular}



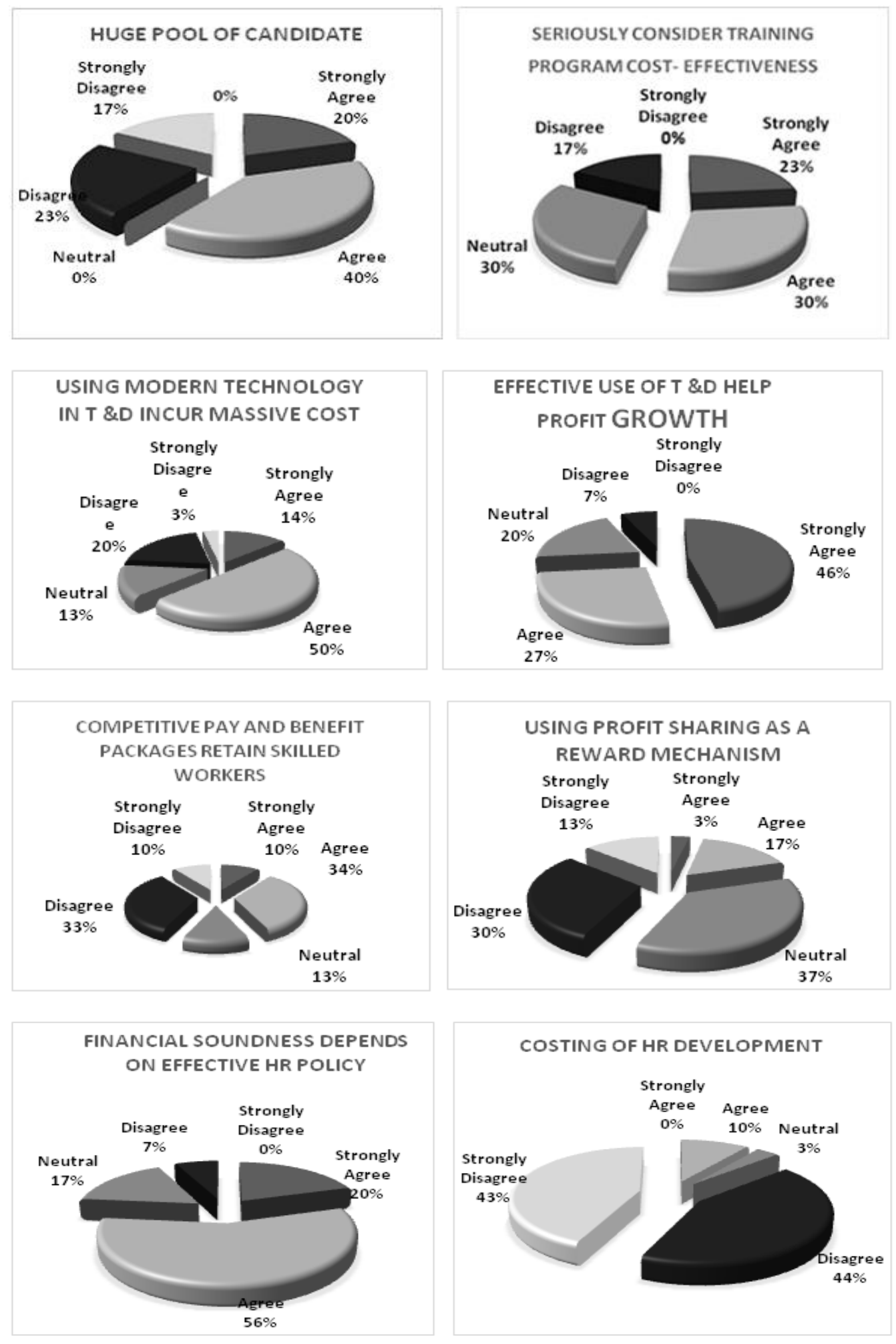


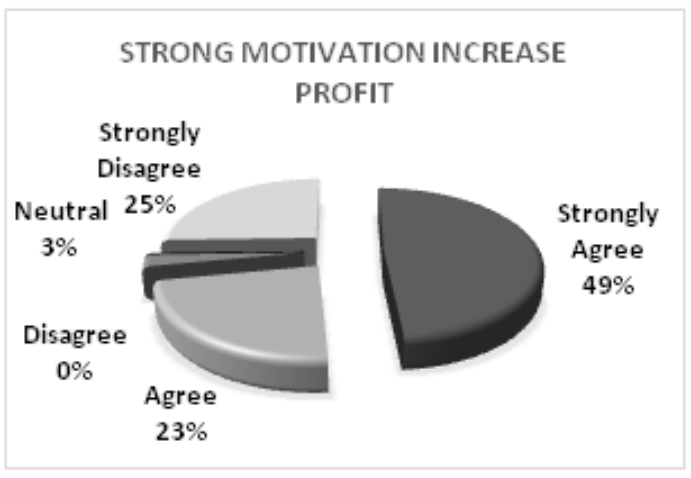

\section{QUALIFIED AND EFFICIENT EMPLOYEES \\ INCREASE SALES GROWTH AND PROFIT}

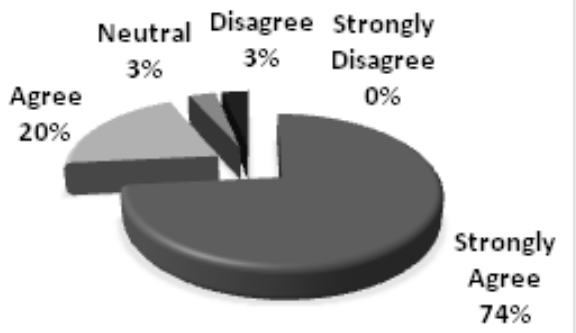

Following scenarios has found;

- Bank wants efficient and skilled employees and for this, they generally test a maximum number of candidates to get the best from the pool and their efficiency increase productivity as well as profit.

- Cost of training and development for the employees do not hamper profit growth in long run though it incur cost and reduce profit in the short run as it helps to increase employee skill.

- $\quad$ Financial soundness of a bank depends on its strong HR policy no doubt.

- Motivation will push up the employees to work in a better proportion which will help to increase profit.

- Competitive pay and benefits packages are provided to attract and retain skilled employees.

\section{Statistical analysis}

Firstly we select ROE as dependent variable and Operating Income per employee and operating profit per branch as independent variables.

Model Summary

\begin{tabular}{|c|c|c|c|c|c|}
\hline Model & R & R Square & $\begin{array}{l}\text { Adjusted } \\
\text { R Square }\end{array}$ & $\begin{array}{l}\text { Std. Error of } \\
\text { the Estimate }\end{array}$ & $\begin{array}{l}\text { Durbin- } \\
\text { Watson }\end{array}$ \\
\hline 1 & $.960(\mathrm{a})$ & .923 & .845 & 2.82958 & 2.080 \\
\hline
\end{tabular}

a Predictors: (Constant), Operating profit per branch, Operating Income per employee

Coefficient of correlation (R): It measures the relationship degree of affiliation between the dependent and independent variables. Here, $\mathbf{R}=\mathbf{0 . 9 6 0}$ indicates that there is a positive correlation between the variables. If the independent variable increases then this will result invariable dependent increase accordingly.

Coefficient of Determination $\left(\mathbf{R}^{2}\right)$ : $R^{2}$ illustrates the percentage of the variability in the dependent variable that can be described by the estimated multiple regression equations. Here $R^{2}$ is equal to $\mathbf{0 . 9 2 3 i n d i c a t e s} \mathbf{9 2 . 3 \%}$ of the variability in ROE is explained by the independent variable.

Durbin Watson test (D): Here, $\mathrm{D}=2.080$ which shows no autocorrelation problem exist in this case. 
ANOVA(b)

\begin{tabular}{|c|c|c|c|c|c|c|}
\hline Model & & Sum of Squares & Df & Mean Square & F & Sig. \\
\hline 1 & Regression & 190.768 & 2 & 95.384 & 11.913 & $.077(\mathrm{a})$ \\
\hline & Residual & 16.013 & 2 & 8.007 & & \\
\hline & Total & 206.781 & 4 & & & \\
\hline
\end{tabular}

a Predictors: (Constant), Operating profit per branch, Operating Income per employee

b Dependent Variable: ROE

\section{F-Test:}

The F-Test, which used to determine whether a significant relationship prevails between the dependent variable and independent variables. It is considered as the test for overall significance of the variables jointly. Here the hypothesis for the F test is deemed as there is no significant relationship between dependent and independent variables. The alternative hypothesis is vice versa.

Therefore the null hypothesis is:

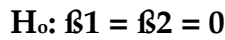

\section{$\mathrm{Ha}_{\mathrm{a}}$ one of the parameters is not equal to zero}

If the null hypothesis is rejected, we can conclude that the overall relationship between $\mathbf{Y}$ and independent variables is significant.

Test Statistic, F= MSR/MSE

\subsection{3}

As the $\alpha$ is lower than the level of significance of $10 \%(\alpha=0.077)$, so it has certainly derived that the null hypothesis is rejected, so, the overall relationship is significant.

Regression Analysis:

Coefficients (a)

\begin{tabular}{|c|c|c|c|c|c|}
\hline Model & \multicolumn{2}{|c|}{ Unstandardized Coefficients } & \multirow{2}{*}{\begin{tabular}{|c|} 
Standardized Coefficients \\
Beta
\end{tabular}} & \multirow[b]{2}{*}{$\mathrm{T}$} & \multirow[b]{2}{*}{ Sig } \\
\hline \multirow{4}{*}{$\begin{array}{c}1 \\
\text { (Constant) } \\
\text { Operating Income per employee } \\
\text { Operating profit per branch }\end{array}$} & B & Std. Error & & & \\
\hline & -36.015 & 16.319 & & -2.207 & .158 \\
\hline & 1.937 & 1.403 & -.923 & -1.380 & .302 \\
\hline & 1.155 & .428 & 1.804 & 2.696 & .114 \\
\hline
\end{tabular}

a Dependent Variable: ROE

Here,

From the output above we can bring out an equation that is like:

$Y=\beta_{0}+\beta_{1} X_{1+} \beta_{2} X_{2}$

$\mathrm{ROE}=-36.015+1.197$ Operating Income per employee +1.155 Operating profit per branch

Here it is found that all the relationships are positive, but most of them are not highly significant individually.

\section{Finding from statistical results:}

As a whole it reveals that as the number of branches and employees increase, the efficiency and productivity of employees will push the profit of the bank. 


\section{CONCLUDING REMARKS}

The HR costs generally consider as expenses for any banks which definitely reduce a part of profit, but its long-term effects are quite positive over the profit growth of a bank. The study reveals that the selected bank mainly focuses on their cost effective training and development program to increase their employee's effectiveness which also boost up their profit margin. The bank always strictly follows the market trend regarding giving compensation and incentives which eventually increase the skills and efficiency of employees as well as the profitability of the bank. In banking sector customers satisfaction mainly depends on the efficiency of the employees activities which ultimately increase sales and so banks generally emphasize on HR policy development. Strong recruitment and impartial selection process help bank to identify and select eligible candidates which mainly increase bank's productivity. The confidential or sensitive data and information for obvious reason posed an obstacle to preparing the paper which the bank didn't provide the outsider which is one of the limitations of the research and another one is non-availability of data and information that are more recent on different activities of those banks which are useful to depict the actual and up-to-date business position of the bank. Although it has found that the bank usually spends a significant amount of money for HR policy development, in the long run, it returns those cost as a form of profit.

\section{REFERENCES}

Absar, Mir Mohammed Nurul, Nimalathasan, Balasundaram and Jilani, Munshi Muhammad Abdul Kader. Impact of HR Practices on Organizational Performance in Bangladesh. JANUARY 2010.

Academy of Management Review, 14: 423-444. Weitzman, M. L., \& Kruse, D. L. 1990. Profit sharing and productivity.

Ahmed, Faruq, and Bhuiyan, Mohammad, Moqbul, Hossen, (2002), "Experiences of Bangladeshi Companies in Strategic Human Resource Management", Dhaka University Journal of Business Studies, Vol. XX111, No. 1, June 2002, ISSN 1682-2498. pp. 97- 106.

Arthur, J.B., 1994. Effects of human resource systems on manufacturing performance and turnover. Academy of Management Journal 37 (3), 670-687

Bartel, A. P. 1994. Productivity gains from the implementation of employee training programs. Industrial Relations, 33: 411-425.

Becker, B. E., and Fuseli, M. A. (1998), High-Performance Work Systems and Firm Performance: A Synthesis of Research and Managerial Implications: Research in Personnel and Human Resource Management, Vol.16, pp. 53-101.

Begin, J. P. 1991. Strategic employment policy: An organizational systems perspective. Englewood Cliffs, NJ: Prentice-Hall.

Brown, C., \&Medoff, J. 1978. Trade unions in the production process. Journal of Political Economy, 86: 355-378.

Brown, Donaldson. 1912. Dupont analysis. 9 December 2015. Wikipedia. August 01, 2015. $<$ https://en.wikipedia.org/wiki/DuPont_analysis>.

Butler, J. E., Ferris, G. R., \& Napier, N. K. 1991. Strategy and human resources management. Cincinnati: South-Western.

Cappelli, P., \& Singh, H. 1992. Integrating strategic human resources and strategic management. In D.

Delaney JT, Lewin D, Ichniowski. 1989. Human resources policies and practices in American firms. US Department of Labor: US Government Printing Office.

Dessler, G., Human Resources Management, Pearson Education, Inc. 2005 
Gerhart, B., \&Milkovich, G. T. 1992. Employee compensation: Research and practice. In M. D. Dunnette\& L. M. Hough (Eds.), Handbook of industrial and organizational psychology, vol. 3: 481-569.

Guzzo, R. A., Jette, R. D., \&Katzell, R. A. 1985. The effect of psychologically based intervention programs in worker productivity: A meta-analysis. Personnel Psychology, 38: 275-291.

Holzer, H. J. 1987. Hiring procedures in the firm: Their economic determinants and outcomes. Dhaka Bank Limited.15 October 2015. <www.dbl.bd.com>.

Horngren, C.T., Foster, G., and Datar, S.M. (2000), Cost Accounting: Managerial Emphasis, Prentice Hall, New Delhi.

HUMAN RESOURCE MANAGEMENT AND PRODUCTIVITY, Nicholas Bloom\& John Van Reenen, Working Paper 16019, http://www.nber.org/papers/w16019, NATIONAL BUREAU OF ECONOMIC RESEARCH, 1050 Massachusetts Avenue, Cambridge, MA 02138, May 2010

Integrated manufacturing and human resource manage-ment: A human capital perspective. Academy of Management Journal, 35: 467-504. 1995 Huselid 671

Jackson, S. E., \& Schuler, R. S. 1995. Understanding human resource management in the con-text of organizations and their environments.

Karim, Tahniyat Ahmed, Personal interview, Executive Vice President, Department of Human Resource, Dhaka Bank Ltd.

Katou, A. A., and Budwar, P. S. (2007), The Effects of Human Resource Management Policies On Organizational Performance In Greek Manufacturing Firms. Thunderbird International Business Review, Vol.49, No.1, pp.1-35.

Katz, H. C., Kochan, T. A., \& Keefe, J. H. 1987. Industrial relations and productivity in the U.S. automobile industry. Washington, DC: Brookings Institution.

Katz, H. C., Kochan, T. A., \& Weber, M. R. 1985. Assessing the effects of industrial relations systems and efforts to improve the quality of working life on organizational effectiveness. Academy of Management Journal, 28: 509-526.

Katz, H. C., Kochan, T. A., \&Gobeille, K. R. 1983. Industrial relations performance, economic performance, and QWL programs: An Interplant analysis. Industrial and Labor Relations Review, 37: 3-17. 670 June This content downloaded from 202.74.245.21 on Sun, 2 Nov 2014 03:11:44 AM All use subject to JSTOR Terms and Conditions.

Khasru, Darashiko, Personal interview, Chief Financial Officer, Department of Accounts \& Finance, Dhaka Bank Ltd.

MacDuffie, J. P. 1995. Human resource bundles and manufacturing performance: Organizational logic and flexible production systems in the world auto industry.

Manufacturing businesses. NBER working paper series no. 3449, National Bureau of Economic Research. Cambridge, MA. Ichniowski, C., Shaw, K., \&Prennushi, G. 1993.

Moyeen, A. F. M. A., and Huq, A.(2001), Human resource management practices in business enterprises in Bangladesh: Journal of Business Studies,Vol. Xxii, No.2, pp.263-270.

Noe, R. A., Hollenbeck, J. R., Gerhart, B., and Wright, P. M. (2007), Human Resource Management: Gaining a competitive advantage, McGraw-Hill, USA.

Porter, M. E. 1985. Competitive advantage: Creating and sustaining superior performance. New York: Free Press

Schuler, R. S. 1992. Strategic human resource management: Linking people with the needs of the business. Organizational Dynamics, 20: 19-32

Talukder, Md.Farid Hossain, Hossain,Md.Yahin, Hossain, Md. Nahin. HRM practice in commercial banks: A case study of Bangladesh. IOSR Journal of Business and Management (IOSR-JBM)eISSN: 2278-487X, p-ISSN: 2319-7668. Volume 16, Issue 2. Ver. III (Feb. 2014), PP 29-36.

The Schuster report: The proven connection between people and prof-its. New York: Wiley. Schuster, M. 1983. 
Union membership and contract coverage in the United States. Industrial and Labor Relations Review, 44: 5-33. Cutcher-Gershenfeld, J. 1991.

Wright, P. M., \& McMahan, G. C. 1992. Theoretical perspectives on strategic human resource management. Journal of Management, 18(2): 295-320.

$--0-$ 